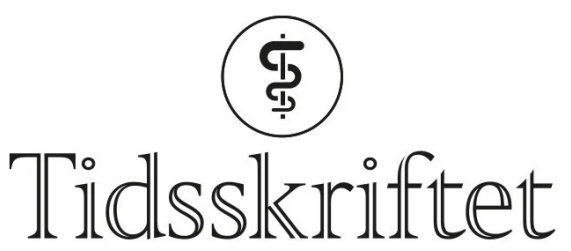

DEN NORSKE LEGEFORENING

\title{
Asymptomatisk covid-19 med usikre testresultater
}

KORT KASUISTIKK

\section{ARNE JOHAN NORHEIM}

arne@avital.no

Institutt for militær allmennhelse

Forsvarets sanitet, Sessvollmoen

og

Nasjonalt forskningssenter innen komplementær og alternativ medisin

UiT - Norges arktiske universitet

Arne Johan Norheim er spesialist i allmennmedisin, instituttsjef og professor i

helsetjenesteforskning. Han er prosjektleder for utvidet systematisk infeksjonsovervåking mot covid19 i Forsvaret.

Forfatteren har fylt ut ICMJE-skjemaet og oppgir ingen interessekonflikter.

\section{ANDREAS LIND}

Avdeling for mikrobiologi

Oslo universitetssykehus, Ullevål sykehus

Andreas Lind er spesialist i medisinsk mikrobiologi, i indremedisin og i infeksjonssykdommer, og har det medisinske ansvaret for SARS-CoV-2-diagnostikken ved Oslo universitetssykehus.

Forfatteren har fylt ut ICMJE-skjemaet og oppgir ingen interessekonflikter.

\section{ARNE MICHAEL TAXT}

Avdeling for mikrobiologi

Oslo universitetssykehus, Ullevål sykehus

Arne Michael Taxt er spesialist i barnesykdommer og lege i spesialisering i medisinsk mikrobiologi.

Forfatteren har fylt ut ICMJE-skjemaet og oppgir ingen interessekonflikter.

\section{ESPEN ROSTRUP NAKSTAD}

Nasjonal behandlingstjeneste for CBRNE-medisin (CBRNE-senteret)

Akuttmedisinsk avdeling

Oslo universitetssykehus, Ullevål sykehus

Espen Rostrup Nakstad er ph.d., spesialist i indremedisin og i lungesykdommer, overlege og senterleder.

Forfatteren har fylt ut ICMJE-skjemaet og oppgir ingen interessekonflikter.

\section{EINAR KRISTIAN BORUD}

Forsvarets helseregister

Forsvarets sanitet, Sessvollmoen

Einar Kristian Borud er spesialist i allmennmedisin og i samfunnsmedisin. Han er registeransvarlig ved Forsvarets helseregister.

Forfatteren har fylt ut ICMJE-skjemaet og oppgir ingen interessekonflikter. 


\section{Testing for SARS-CoV-2 ved bruk av PCR- og antistofftester gir et betydelig bidrag i bekjempelsen av covid-19-pandemien. Denne kasuistikken belyser en situasjon der PCR-testing for SARS-CoV-2 reiste flere spørsmål enn testen kunne besvare.}

En tidligere frisk mann møtte utfordringene rundt covid-19 ved å skjerme seg fra kontakt med andre personer fra mars 2020 frem til han i april samme år skulle avtjene førstegangstjeneste ved rekruttskolen KNM Harald Haarfagre på Madla i Stavanger. Hjemme var han alene om å bruke det ene av husets to bad med toalett, men han spiste måltidene sammen med øvrige husstandsmedlemmer. Medio mars fikk husstanden besøk av den blivende rekruttens utflyttede søster, som var litt «snufsete», men ikke i en slik grad at det vekket mistanke om covid-19. Ingen andre i familien hadde hatt luftveissymptomer eller mistanke om smitte med koronavirus, men de hadde heller ikke vært til noen form for testing. Forsvaret hadde under innrykket på rekruttskolen iverksatt såkalt utvidet systematisk infeksjonsovervåking(USI)(1). Dette omfattet utvidet egenerklæring om helse og temperaturmåling ved oppmøte samt hurtigtest for påvisning av antistoffer mot SARSCoV-2, venøs blodprøve til serologisk analyse av antistoffer, og dyp neseprøve og halsprøve til påvisning av SARS-CoV-2-RNA i øvre luftveier (ved polymerasekjedereaksjon, PCR). PCR og serologiske undersøkelser ble gjentatt rutinemessig hos alle rekruttene etter tre og seks uker i løpet av åtte ukers rekruttskole (figur 1).

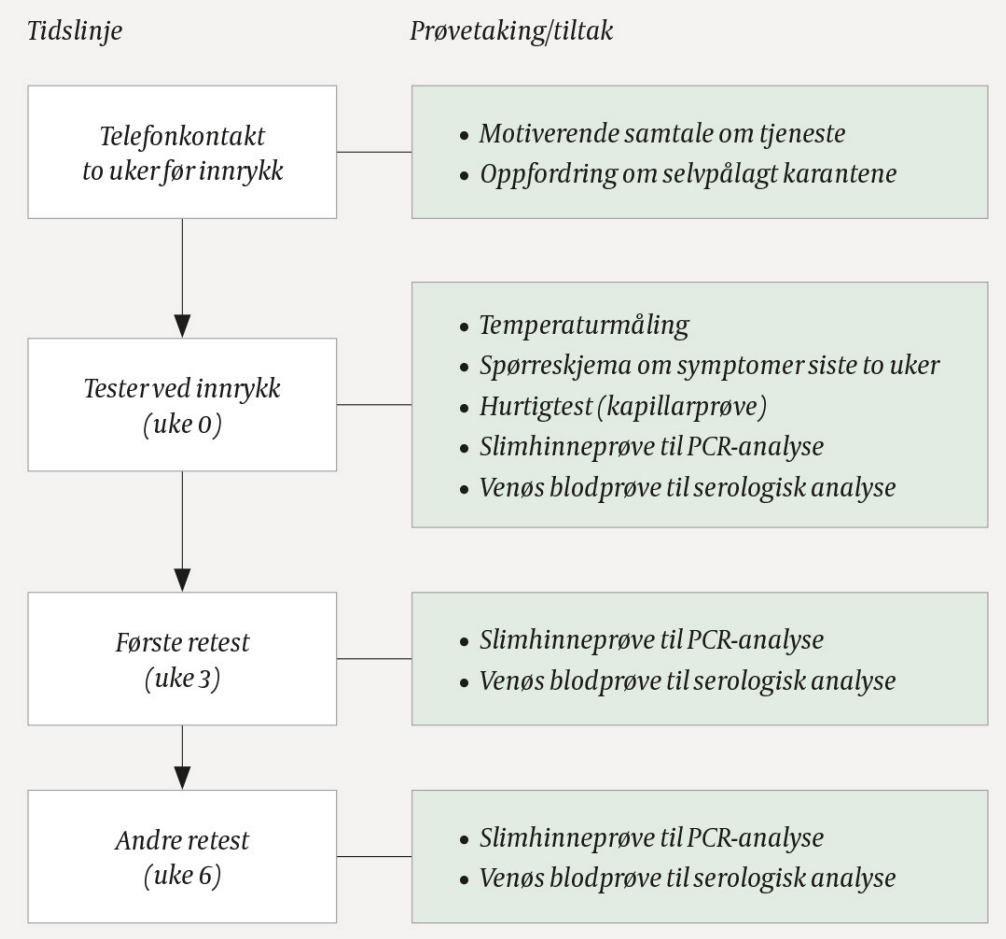

Figur 1 Forsvarets testprogram for utvidet systematisk infeksjonsovervåking (USI). I forbindelse med innrykk av nye rekrutter til Forsvaret ble det iverksatt en rekke tiltak, deriblant symptomkartlegging, temperaturmåling og testing for SARS-CoV-2 med hurtigtest, PCR-test og serologisk test ved innrykk (uke o) samt retesting med PCR-test og serologisk test etter tre og seks uker. 
Ved oppmøte var mannen afebril og uten luftveissymptomer. Han testet imidlertid positivt på IgG og negativt på IgM på hurtigtest for antistoffer mot SARS-CoV-2. Han ble satt i karantene, men denne ble opphevet dagen etter ettersom PCR-svaret var negativt. Deretter inngikk han i ordinær rekruttskole og fulgte videre rutinemessig prøvetaking. Også serologisk analyse av prøve tatt ved oppmøte var positiv (tabell 1 ).

\section{Tabell 1}

Resultater av pasientens tester for SARS-CoV-2.

\begin{tabular}{|lllll|}
\hline Test & Uke o & Uke 3 & Uke 6 & $\begin{array}{l}\text { Uke 6 } \\
\text { (kontroller) }\end{array}$ \\
\hline Hurtigtest $^{1}$ & Positiv (IgG) & - & - & - \\
\hline PCR-test $^{2}$ & Negativ & Negativ & $\begin{array}{l}\text { Positiv } \\
\left(\mathrm{Ct}^{3}=35,48\right)\end{array}$ & Negativ $(\times 2)$ \\
\hline $\begin{array}{l}\text { Serologisk test } \\
(\mathrm{S} / \mathrm{Co})^{5}\end{array}$ & $\begin{array}{l}\text { Positiv } \\
(18,7)\end{array}$ & $\begin{array}{l}\text { Positiv } \\
(20,3)\end{array}$ & $\begin{array}{l}\text { Positiv } \\
(23,2)\end{array}$ & - \\
\hline
\end{tabular}

${ }^{1}$ Acro 2019-nCoV IgG/IgM rapid antibody test

${ }^{2}$ Cobas SARS-CoV-2

${ }^{3} \mathrm{Ct}=$ cycle threshold.

${ }^{4}$ Elecsys IgM/IgG Anti-SARS-CoV-2 assay

${ }^{5}$ Analysen gir en totalmåling av IgG og IgM, og uttrykker dette som en indeks som er et forholdstall mellom signalet målt i prøven (IgG og IgM) og signalet fra en intern kontroll i assayet. Produsenten kaller det signal-to-cut-off ratio, og forkorter dette til S/Co.

Tre uker etter innrykk hadde rekrutten fortsatt ingen symptomer, og PCR-test ved rutinemessig oppfølging var negativ. Det ble påvist stigende antistoffnivå ved rutinemessig serologisk testing. Ved prøvetaking etter seks uker var han fortsatt uten symptomer, men den rutinemessige PCR-analysen av prøve fra nasofarynks var positiv. Prøven ble analysert med samme metodikk og ved samme laboratorium som de to foregående PCR-prøvene. Rekrutten hadde også hatt ytterligere antistoffstigning i de serologiske testene (tabell 1).

Positiv PCR-test ble meldt til kommuneoverlege og Meldingssystem for smittsomme sykdommer (MSIS), og rekrutten ble satt i isolasjon. Dagen etter ble det i samråd med helsemyndigheter tatt kontrollprøver som ble analysert ved to ulike laboratorier. Begge kontrollprøvene ga negativt testresultat (tabell 1). Etter rådføring med Folkehelseinstituttet og smittevernoverlege i Stavanger kommune ble rekrutten tatt ut av isolasjon. Han fullførte den resterende delen av rekruttskolen uten noen symptomer, og har ikke vært syk etter at han var ferdig på rekruttskolen i juni 2020.

\section{Diskusjon}

Soldaten hadde ikke hatt noen covid-19-assosierte symptomer verken før, under eller etter oppholdet på rekruttskolen. Likevel fikk han positiv hurtigtest ved innrykk, positive antistofftester med svakt stigende nivå av antistoffer mot SARS-CoV-2, og svakt positiv PCRtest for SARS-CoV-2-RNA ved siste prøvetakning i uke 6.

Stigende nivåer av antistoff mot SARS-CoV-2 hos vår pasient er utfordrende å tolke. IgG/IgMantistoff ved covid-19 beskrives å opptre innen få dager, men også opptil en uke etter symptomdebut. Utviklingen beskrives noe ulikt for IgG og IgM, men konsentrasjonen når 
et maksimum flere uker etter at pasienten har hatt de første symptomene, blant annet pga. antistoffenes aviditet $(\underline{2}, 3)$. Foreløpig mangler gode beskrivelser av serodynamikk hos symptomfrie pasienter.

Positive serologiske tester for SARS-CoV-2 kan tyde på gjennomgått infeksjon allerede før innrykk, uten at dette kom frem anamnestisk eller ved de første PCR-testene. Testen som ble brukt (Roche Elecsys Anti-SARS-CoV-2), har en sensitivitet på over $95 \%$ og en spesifisitet på over $99 \%$ (4).

Uspesifikk reaktivitet eller kryssreaktivitet med antistoffer mot andre koronavirus vil kunne føre til falskt positive serologiske tester, men S/Co-verdien (signal-to-cut-off ratio) ville da høyst sannsynlig ha vært lavere og heller ikke ha steget suksessivt over den korte perioden antistoffmålingene ble gjort.

Det svakt positive resultatet av PCR-testen for SARS-CoV-2-RNA ved siste rutinemessige prøvetakning i uke 6 lot seg ikke reprodusere. Dette kan enten forklares av meget lave mengder virus-RNA, ikke levedyktig virus (5) eller et falskt positivt resultat.

PCR-analysen av de to første prøvene og kontrollprøvene kan ha gitt falskt negativt resultat. Andre har også rapportert tilfeller av positiv PCR etter to forutgående negative tester tatt med 24 timers mellomrom, og angir at dette kan skyldes falskt negativ test, reinfeksjon eller reaktivering (므). Mulige forklaringer kan være virusets sterke binding til reseptorer i nedre luftveier og fravær av hoste som eksponerer agens. Videre kan tildekking (coating) av antistoff på virus vanskeliggjøre antigenpåvisning, men ikke RNA-påvisning. Det er også mangelfullt kartlagt hvordan SARS-CoV-2-virus utskilles (shedding), særlig langt ut i sykdomsforløpet (7.). Forbytting av prøver er en teoretisk mulighet, men svært usannsynlig i lys av svært strenge prosedyrer.

Samlet vurdering av serologiske undersøkelser og PCR-analyser tyder etter vår mening på gjennomgått asymptomatisk infeksjon før innrykk.

Det at vår pasient ikke har smittet andre, kan være uttrykk for lav grad av smitteoverføring. Det er imidlertid ikke gitt at pasienter med asymptomatisk infeksjon har lavere grad av smitteoverføring enn pasienter med symptomer. Den høye Ct-verdien (cycle threshold) på over $35 \mathrm{i}$ den positive PCR-testen indikerer at det må ha vært lite virus-RNA til stede $\mathrm{i}$ prøven. Det har også blitt vist at SARS-CoV-2 isolert fra slimhinneprøver med høye PCR-Ctverdier ikke har latt seg dyrke og dermed ikke lenger er viable (요). Fravær av smittespredning kan også være uttrykk for effekt av gode smitteverntiltak eller at pasienten ikke var smitteførende.

Kasuistikken illustrerer at gjentatt PCR-test kan fange opp virus-RNA selv om forutgående tester har vært negative, og det ikke har vært interkurrent sykdom. Den viser også samsvar mellom positivt resultat ved antistoffbasert hurtigtest og venøs blodprøve, og at serologiske analyser kan være et verdifullt supplement ved tolkning av PCR-resultater. Historien belyser også utfordringene man kan få ved screening av asymptomatiske personer i stor skala.

Pasienten har gitt samtykke til at artikkelen blir publisert.

Artikkelen er fagfellevurdert.

\section{LITTERATUR}

1. Norheim AJ, Nakstad E, Berg AS et al. Testing for covid-19 ved innrykk til Forsvaret. Tidsskr Nor Legeforen 2020; 140. doi: 10.4045/tidsskr.20.0384. [PubMed][CrossRef]

2. Lijia S, Lihong S, Huabin W et al. Serological chemiluminescence immunoassay for the diagnosis of SARS-CoV-2 infection. J Clin Lab Anal 2020; 34: e23466. [PubMed][CrossRef]

3. Xiang F, Wang X, He X et al. Antibody detection and dynamic characteristics in patients with covid19. 2020; ciaa461. 
4. Evaluation of sensitivity and specificity of four commercially available SARS-CoV-2 antibody immunoassays London: Public Health England, University of Oxford, Oxford University Hospitals NHS Foundation Trust, 2020.

https://assets.publishing.service.gov.uk/government/uploads/system/uploads/attachment_data/file/8 98437/Evaluation__of_sensitivity_and_specificity_of_4_commercially_available_SARS-CoV2_antibody_immunoassays.pdf Lest 2.11.2020.

5. Wölfel R, Corman VM, Guggemos W et al. Virological assessment of hospitalized patients with COVID-2019. Nature 2020; 581: 465-9. [PubMed][CrossRef]

6. Sethuraman N, Jeremiah SS, Ryo A. Interpreting diagnostic tests for SARS-CoV-2. JAMA 2020;323: 2249-51. [PubMed][CrossRef]

7. Yan D, Liu XY, Zhu YN et al. Factors associated with prolonged viral shedding and impact of lopinavir/ritonavir treatment in hospitalised non-critically ill patients with SARS-CoV-2 infection. Eur Respir J 2020; 56: 2000799. [PubMed][CrossRef]

8. La Scola B, Le Bideau M, Andreani J et al. Viral RNA load as determined by cell culture as a management tool for discharge of SARS-CoV-2 patients from infectious disease wards. Eur J Clin Microbiol Infect Dis 2020; 39: 1059-61. [PubMed][CrossRef]

Publisert: 14. desember 2020. Tidsskr Nor Legeforen. DOI: 10.4045/tidsskr.20.0658

Mottatt 17.8.2020, første revisjon innsendt 21.9.2020, godkjent 2.11.2020.

Publisert under åpen tilgang CC BY-ND. Lastet ned fra tidsskriftet.no 26. april 2023. 